\title{
REFORMASI EKONOMI BERBASIS BAGI HASIL BELAJAR DARI SISTEM EKONOMI SOSIALIS
}

\section{F. Setiawan Santoso}

Dosen Fakultas Agama Islam Universitas Cokroaminoto Yogyakarta

fattah_ss@yahoo.com

\begin{abstract}
Abstrak
Pengalaman ekonomi sosialis yang dianut oleh Uni Soviet (USSR) dan Republik Rakyat Cina (RRC) dapat menjadi pelajaran bagi Negara-negara muslim melaksanakan ekonomi non-ribawi dan berbasis bagi hasil. Fokus dari penelitian ini adalah sistem ekonomi sosialis pasar dalam mengatasi isu-isu reformasi dalam meningkatkan pertumbuhan ekonomi. Isu kordinasi antara birokrasi pemerintah dan kebebasan pasar ternyata masih menjadi hambatan bagi pertumbuhan ekonomi yang optimal. Birokrasi yang panjang telah berpengaruh terhadap kepekaan reaksi pasar kedua untuk merespon pergerakan ekonomi global.
\end{abstract}

Kata kunci: ekonomi sosialis, Uni Soviet (USSR), Rakyat Cina (RRC), reformasi ekonomi.

\section{A. PENDAHULUAN}

Di awal-awal pertumbuhannya, sistem ekonomi sosialis diorganisir seperti piramida, dengan kepemimpinan partai dan pemerintah berada di puncak, perusahaan dan swasta berada di tahapan dasar, sementara kementerian untuk sektor-sektor tertentu menguasai lapisan pertengahan. Model organisasi komando kemudian secara teratur mengalami perubahan terutama pada lapisan bawah dan tengah, perusahaan dan kementrian, kadang dipisah kemudian digabungkan. Pada kesempatan yang lain, lapisan bawah dialihkan dari pelayanan satu mentri kepada yang lain, fungsi-fungsinya didistribusikan lagi antar staf dan jajaran departemen-departemen. Perubahan-perubahan itu dilakukan mengingat arti penting reformasi ekonomi dalam perumusan dan implementasi sistem ekonomi sosialis komando. 
Reformasi mengenalkan pemanfaatan nilai-nilai ekonomi dalam sistem ekonomi komando. Dengan memaksud meningkatkan performa ekonominya, Negara sosialis bisa menggunakan ukuran efisiensi seperti halnya yang terjadi pada Negara penganut sistem pasar. Implementasinya memang tidak mudah karena karakter pokok kebersamaan perlu diinterpretasikan lebih lanjut, demikian pula formulasi efisiensi perlu adjustment agar tidak menyimpang dari nilai dan tujuan.

Trend reformasi ekonomi sosialis mengkerucut pada tahun 1980-an akibat situasi krisis energi dunia. Krisis itu telah membawa hampir semua negara di dunia mengalami hutang tak terbayarkan dalam waktu singkat, termasuk di antaranya, Uni Soviet (USSR) sebagai induk sistem komando dari berbagai Negara sosialis Eropa Timur dan Republik Rakyat Cina (RRC). Dengan mendeksripsikan mengetahui sistem perencanaan, resepsi terhadap teknologi dan sistem insentif yang dikembangkan sepanjang 1980-1990 akan diketahui pola reformasi ekonomi yang dijalankan oleh kedua negara dan problem yang dihadapi di masa datang.

Pengalaman USSR dan RRC bisa dimanfaatkan oleh Negara-negara muslim yang menginginkan sistem ekonominya berbasis syariah dibandingkan ekonomi ribawi. Keduanya telah merasakan bagaimana keunggulan dan kekurangan ekonomi non-ribawi dan aplikasi sistem bagi hasil sebagai tolok ukur dalam menjalankan perekonomiannya. Semua itu dapat dipelajari, diidentifikasi dan diseleksi oleh ekonom muslim untuk mengelola aktivitas ekonomi negara yang mensejahterakan rakyat tetap berbasis Islam.

Deskripsi tidak mengarah kepada sistem sosialis komando sebagai awal dari perjalanan sistem ini, namun langsung menuju tahap lanjutannya, yaitu sistem ekonomi sosialis pasar. Teori dan pengalaman di tahapan ini lebih memudahkan dalam memahami dan mereaksi gerakan ekonomi global dewasa ini. Selanjutnya analisis dilanjutkan dengan apresiasi sosialis pasar terhadap isu-isu krusial dalam pertumbuhan ekonomi yang terangkum dalam reformasi ekonomi. 


\section{B. KONSEP DASAR SISTEM EKONOMI SOSIALIS PASAR}

Ide sistem ekonomi sosialis tidak bisa dilepaskan dari pemikiran Marx dan Engel tentang sejarah materialisme dunia Barat. Sosialisme diposisikan sebagai satu tahapan yang harus dijalani oleh kapitalisme menuju era komunisme penuh. ${ }^{1}$ Sosialisme menjadi jembatan yang meghubungkan antara dua era sebelum dan sesudahnya. Di era itu, proyek besar yang harus dilakukan adalah transisi massa dari kemiskian dan penderitaan akibat capitalism menuju full communism. Pada tahapan terakhir itu tercipta masyarakat yang egaliter tanpa kelas dalam semangat kebersamaan dan sosial. Alat-alat produksi tidak lagi dikuasai oleh privat tetapi negara yang telah kehilangan karakter politiknya sehingga tidak mampu melakukan eksploitasi dan menindas masyarakat. Setelah kebangkitan sosialism, Marx meyakini bahwa efisiensi dan equiti dapat bergandengan. ${ }^{2}$

Nilai-nilai sosialisme Marx dan Engel kemudian diejawantahkan oleh Lenin menjadi satu sistem ekonomi saat membangun Russia menjadi Uni Soviet (USSR) setelah revolusi Bolshevik. ${ }^{3}$ Lenin menilai organisasi ekonominya lebih mudah dibanding perhitungan pasar. Ia selanjutnya menegaskan, "Operasionalnya luar biasa sederhana; hanya mengamati, mencatat, dan memberikan saran; dalam jangkauan siapapun yang dapat membaca dan menulis dan mengetahui empat rumus pertama perhitungan aritmetika." Lenin melakukan kesalahan yang berakibat Soviet pada penurunan produksi $14 \%$ dibanding pertumbuhan sebelum revolusi. Pada tahun 1921, Lenin terpaksa mendirikan New Economic Policy (NEP) yang mengadaptasi secara parsial insentif pasar dari kapitalisme. Model campuran sosialisme dan kapitalisme berakhir dalam 1927 setelah Stalin memulai kolektivisasi yang memaksa pengerahan seluruh sumber daya Rusia untuk membuat lompatan besar di bidang industri. ${ }^{4}$

Sosialisme didefinisikan oleh Heilbroner sebagai a centrally planned economy in which the government controls all means of production. ${ }^{5}$ Sebagai sistem ekonomi dalam satu komando, sosialisme menempatkan posisi negara sebagai sentral kegiatan ekonmi dengan ciri-ciri sebagai berikut; ${ }^{6}$

1. Negara sangat berkuasa dalam kepemilikan bersama terhadap semua faktor produksi. 
2. Produksi dilakukan sesuai dengan kebutuhan. Negara akan mengatur semua produksi barang yang dibutuhkan oleh masyarakat, bukan hanya barang dan jasa yang bernilai ekonomi karena seluruh kegiatan ekonomi tidak diarahkan untuk menimbun kekayaan individu tetapi kesejahteraan bersama.

3. Perencanaan ekonomi yang ketat untuk memproduksi dan mendistrbusikan barang dan jasa yang dibutuhkan oleh masyarakat. Mekanisme pasar tidak lagi berlaku karena negara yang menentukan semua harga (price setter)

Ekonomi sosial komando model Soviet yang serba terpusat dan terpimpin telah menimbulkan problem perhitungan dan kalkulasi berlarutlarut. Kesulitan untuk memperoleh dan menguasai informasi yang melimpah oleh pembuat perencanaan pembangunan dirasa sangat berat untuk diatasi. Kegalan dalam mengatasi masalah itu berdamapak pada bagaimana peran lembaga kordinasi dan modifikasi mekanisme pasar dalam menentukan fungsi alokasi sumber daya sulit dilakukan secara efisien. Kelemahan terhadap informasi inilah menjadi sasaran kritikan dari Ludwig Von Misses yang didukung oleh Hayek. ${ }^{7}$

Kegagalan untuk mendapatkan informasi yang akurat direspon oleh Oskar Lange dengan menekankan pada kebutuhan dan pengolahan informasi ekonomi tiap tingkatan pasar. Ia menjelaskan bahwa perencana mempunyai informasi yang tepat ketika memandu pasar. Informasi itu berupa pengetahuan apakah persediaan barang naik atau turun sebagai isyarat penawaran lebih besar dari permintaan atau permintaan lebih besar dari penawaran. Saat planners mengamati tingkat persediaan, mereka belajar mana dari harga administratif yang terlalu tinggi atau rendah. Karena itu, tugasnya tinggal melakukan penyesuaian harga sehingga permintaan dan penawaran seimbang, tepat seperti dalam pasar. ${ }^{8}$

Lange kemudian membangun pasar sosialis dalam tiga tingkatan, tingkat terbawah adalah skala perusahaan privat dan rumah tangga. Tingkat kedua ditempati oleh kementrian perindustrian dan yang tertinggi dikuasai oleh Badan Perencanaan Pusat (Central Planning Board/CPB). Level privat memproduksi output yang marginal cost-nya sesuai dengan harga pasar. Di level dasar itu, wilayah pengambilan keputusan dibatasi antara pilihan kerja 
atau kesenangan. Termasuk dalam wilayah itu, bagaimana mengalokasikan pendapatan dan tenaga kerja. Sedang kementrian dalam keputusan perluasan produksi sektoral.

Pengambilan keputusan tertinggi berada di tangan CPB. Tugasnya adalah menetapkan harga administratif yang ditetapkan, kadang kala, tidak selalu menampilkan kondisi suplai dan penawaran pasar sebenarnya. Agar suplai dan penawaran barang mengalami equilibrium, CPB hendaknya mengusahakan dengan metode trial-error. Jika suplai sebuah barang mengalami surplus, CPB seharusnya menetapkan harga lebih rendah, begitu pula sebaliknya. Proses penyesuaian dilakukan berulang-ulang sampai suplai dan penawaran benar-benar bertemu pada satu titik. Cara itu bermanfaat untuk menghasilkan informasi secara efisien dan berdampak proses konvergensi yang lebih cepat untuk menghasilkan materi informasi yang unggul dibandingkan bila upaya itu dilakukan oleh sektor privat. ${ }^{9}$

Tugas CPB selain penetapan harga berupa tanggung jawab untuk melakukan pemerataan pendapatan berupa dividen sosial. Karena semua factor produksi non-tenaga kerja dimiliki oleh Negara, maka keputusan pembagian sewa dan keuntungan masih tetap di tangannya. Untuk distribusi pendapatan dalam bentuk pelayanan publik, keputusannya dilaksanakan sepenuhnya oleh CPB sebagai pemegang otoritas tertinggi, Untuk pengambilan keputusan investasi, CPB melakukan kordinasi dengan otoritas perindustrian. Tugas lain yang tak kalah berat, tanggung jawab untuk menetapkan dan mengontrol besaran dan arah sistem ekonomi. Lange berargumen bahwa setiap investasi harus sesuai dengan marginal rates of return untuk masing-masing sector. ${ }^{10}$ Meski menyarankan struktur birokrasi yang berlapis namun Lange juga memahami bahwa implementasi reformasi ekonomi dalam ekonomi sosialis sangat tergantung pada proses birokratisiasi. Proses itulah yang sebenarnya menjadi ancaman saat ekonomi sosialis berjalan. ${ }^{11}$

Akhirnya, Zdenik Srein, mencatat bahwa proses transformasi sistem ekonomi sosialis memiliki karakter sebagai berikut:

1. Perubahan mendasar pada peran harga dari sistem tetap (adminstratif) kepada harga pasar dan orientasi profit. Keduanya telah menjadi prinsip dasar bagi perusahaan untuk menetapkan apa dan bagaimana barang diproduksi sehingga fleksibilitas kembali terjadi sesuai dengan kondisi 
suplai dan penawaran termasuk dalam perdanganan luar negeri.

2. Otoritas perusahaan berkembang lebih luas untuk menetapkan pemanfaatan pendapatan, alokasinya untuk investasi atau membayar tenaga kerja, dan arah investasi.

3. Kegiatan usaha dalam artian yang sebenarnya, termasuk pemasaran, aktivitas rencana proyek, penelitian teknis permasaran di luar negeri dan lain sebagainya. Organisasi perusahaan industri harus difokuskan kepada setiap sisi produksi dan komersial.

4. Peran perencanaan berubah dari monosentris ke arah sistem polisenteris di mana perusahaan tidak lagi sebatas melaksanakan atau menjabarkan target perencanaan yang terpusat. Spektrum wewenangnya diperluas hingga otonomi perencanaan aktivitasnya sendiri. Dihadapkan dengan perusahaan privat, peran pusat perusahaan dikurangi menjadi dua dua fungsi;

a. Suplai informasi yang bermanfaat sebagai basis pengambilan keputusan pengembangan dan perencanaan.

b. Formulasi basis-basis obyektif dari kebijakan ekonomi pusat dan menetapkan instrument ekonomi yang bermanfaat bagi perusahaan. ${ }^{12}$

\section{ASPEK-ASPEK REFORMASI ${ }^{13}$}

\section{Perencanaan dan Organisasi}

Desentralisasi merupakan isu pokok dalam reformasi namun bukan hal yang baru dalam perjaanan sistem ekonomi sosialis. Rotasi antara desentralisasi dan resentralisasi telah sering dilakukan sebelum tahun 80an. Resentralisasi oleh Ketua Partai Komunis Cina (PKC) Hua Kofeng pada tahun 1976-1978 berdampak buruk. Ambisinya untuk mengusasai teknologi tinggi pada sektor industri pertama yang dikuasai pemerintah telah menimbulkan dampak buruk dalam perekonomian negara. Pola pembangunan ekstensif yang mengandalkan mobilisasi massa (tenaga kerja) dan modal pada sektor tersebut hingga timbul ekonomi biaya tinggi. Prioritas percepatan pertumbuhan pada industri berat itu ternyata diiringi dengan laju defisit 
sehingga mengganggu program pengentasan kemiskinan. Akibat negatif kebijakan yang sama dirasakan pula di USSR hingga tahun 1984. Kondisinya lebih baik dari Cina karena pertumbuhannya hanya stagnan sementara produktivitas modal menurun.

Naiknya petinggi partai yang berjiwa progresif memberikan perubahan dalam sistem ekonmi kedua negara. Untuk RRC, Zhao Ziyang yang telah membuktikan keberhasilan sistem desentralisasi untuk menaikkan kesejahteraan propinsi yang dipimpinnya diserahi tanggung jawab untuk mengembangkannya di tingkat negara tahun 1980. Setelah kematian Andropov, Gorbachev memimpin Soviet dalam perombakan sistem ekonomi komando Soviet menuju sistem yang sama pada tahun 1985 .

Desentralisasi ekonomi yang ditawarkan Gorbachev dalam "Perestroika" mengehendaki perubahan mendasar menyeluruh hingga wilayah politik dan administrasi. Nilai-nilai demokrasi dalam politik seperti pemilihan umum atau pemberlakuan debat terbuka dikembangkan. Otoritas wilayah regional diperluas termasuk otonomi perencanaan higga tingkatan sulit untuk diadakan resentralisasi.

Program ekonomi strategis diarahkan ke pembentukan ekonomi sosialis pasar pada tahun 2000 untuk menjadikan seluruh perusahaan menjadi mandiri. Perusahaan memperoleh mandat untuk merencanakan dan mengorganisasi perusahaanya dalam jangka pendek. Langkah selanjutnya, pengembangan dua sektor ekonomi, yaitu; sektor negara dan privat dalam porsi yang sama di mana sektor negara diberlakukan sistem kompetisi dan decontrol price yang artinya peran birokrasi pemerintah dikurangi. Sektor pertanian dan privat yang tidak terlibat langsung dengan birokrasi pemerintah lebih berpeluang besar menghadapai sistem pasar yang dikembangkan oleh Gorbachev.

Perubahan drastis tidak dilakukan oleh RRC saat mulai kebijakan desentralisasi sejak tahun1978. Administrasi planning dipusatkan kembali di tangan politisi PKC dengan sedikit perubahan pada otonomi pemerintah kota/kabupaten untuk mengkoordinasikan kegiatan ekonominya hingga tingkat regional. Zhao Ziyang yakin perencanaan terpusat menjadi salah satu syarat keberhasilan reformasi ekonomi selain kepemilikan public pada sarana produksi dan pendapatan buruh sesuai dengan kontribusinya. ${ }^{14}$ 
Semua perusahaan di semua sektor mendapat perhatian yang sama untuk mendorong pertumbuhan dalam otonominya, yang berbeda hanya pada pemberlakuan sistem harga. Sektor pertama wajib mengikuti plannig yang direncanakan oleh pusat dengan pengenaan harga administratif sebelum dilepas dalam mekanisme pasar, sedang sektor pertanian (sektor II) dan sektor III yang dihuni oleh privat dan koperasi boleh bersaing mengikuti harga pasar. Dengan demikian RRC tidak mengakomodasi sektor politik sebagai bagian dari reformasi ekonominya dan melakukannya secara bertahap.

Sikap hati-hati RRC daripada Soviet dimaksudkan mengatasi problem birokrasi dalam kebijakan desentralisasi. Pada hakekatnya, kebijakan tersebut merupakan pengurangan intervensi birokrasi dalam wilayah ekonomi. Karakter itu berbeda dengan sistem lama yang serba terpusat dengan dominasi pemerintah yang menyebabkan kelemahan-kelemahan dalam merespon pasar, antara lain dalam efisiensi, pertanggungjawaban dan inisiatif. Perbedaaan itu tidak disadari otoritas Soviet sehingga perubahan yang dilakukan tidak memberikan manfaat bagi pertumbuhan ekonomi. Dalam pertengahan tahun 1989, partai dan birokrat pemerintah telah mengembalikan desentralisasi kepada pola kontrol yang lama.

Perubahan-perubahan yang terjadi belum dipahami oleh seluruh lapisan birokrasi dan masih menggunakan pola lama maka pengambilan keputusan yang menyederhanakan seperti yang biasa terjadi dalam sistem komando akan menghambat dan menggagalkan desentralisasi. Maka penguasaan terhadap unsusr-unsur desentralisasi perlu dilakukan secara intensif. Untuk itu, penyebaran pengetahuan, pemberian pengalaman dan penyiapan birokrasi secara matang perlu dilakukan dengan melakukannya secara bertahap.

Di masa depan, penyiapan aparat pemerintah yang menguasai sistem ekonomi pasar telah mulai dilakukan oleh RRC. Fasilitas pelatihan tentang lingkungan sistem pasar telah disiapkan, pengiriman mahasiswa secara khsusus mempelajari ekonomi pasar di luar negeri ditingkatkan. Dengan semua itu diharapkan pada beberapa tahun kemudian, RRC memiliki sumber daya setingkat manager untuk mengendalikan berbagai perusahaan negara sesuai dengan pengetahuan yang telah dimiliki. 


\section{Pengembangan Teknologi}

Teknologi merupakan elemen inti dalam produksi sistem ekonomi sosialis. Pemerintahan Hua Gofeng telah menyatakan alasan utamanya mengapa ia melakukan resentralisasi pada tahun 1976-1978. Dampak buruk itulah yang ingin dihindari dalam menngunakan teknologi dalam perpektif desentralisasi

Kebijakan desentralisasi membawa perpektif baru terhadap posisi teknologi yang dikembangkan negara-negara sosialis. Kebebasan untuk melakukan perdagangan luar negeri secara terbuka dan bebas tak terbatas pada sesama negara sosialis telah membuka wawasan baru tentang perkembangan teknologi USSR dan RRC dibandingkan negara kapitalis. Gorbachev telah menegaskan, perubahan radikal dalam strateginya berlandaskan ilmu dan teknologi, namun keduanya telah membeku dan kalah bersaing dengan teknologi Barat. ${ }^{15}$ Cina juga mulai memahami arti baru iptek dengan menetapkannya sebagai salah satu sektor target modernisasi dalam Fifth National People's Congress, pada bulan Februari 1978. Pernyataan resmi kembali dinyatakan dalam Konferensi Nasional Ilmu Pengetahuan dan Teknologi dalam tahun yang sama. ${ }^{16}$

Untuk memajukan teknologinya Uni Soviet, RRC dan mayoritas negara sosialis lain mempunyai kecenderungan yang sama, yaitu memilih jalur alternatif dengan mengeluarkan kebijakan peningkatan penanaman modal asing (Foreign Direct Investement/FDI) dalam bentuk perjanjian kerjasama dan modal ventura/MV (joint venture) digalakkan. Dalam kerjasama, perusahaan luar negeri diikat untuk membangun pabrik perakitan teknologi tertentu di negara mitra sosialisnya. Untuk MV, perusahaan berhak sebagian saham dan memperoleh profit atau output, sementara perjanjian kerjasama memperoleh kompensasi jaminan pengembalian investasi beserta keunt ungannnya.

RRC lebih agresif daripada Soviet dalam merangsang investor luar negeri untuk menanam investasi di negaranya. Undang-Undang tentang MV direvisi pada tahun 1978, dilanjutkan dengan pentapan 160 peraturan dan regulasi yang mendukungnya, termasuk pengaturan tentnag PMA boleh memiliki seluruh saham MV. Di sektor tentang kerja, Perlarangan rekrutmen teknisi ekspatriat untuk bekerja dalam negeri kembali diperbolehkan. ${ }^{17}$ 
Sebagian wilayahnya yang strategis dan berada di perbatasan, pada tahun 1980, dikembangkan sebagai Zona Ekonomi Eksklusif (ZEE) di mana perusahaan MV didirikan di sana mendapatkan kemudahan dalam infra struktur, perpajakan dan bea cukai. Sebagai proyek pertama ZEE didirikan di propinsi Guangdong dan Fujian. ZEE kemudian dikembangkan di propinsi lain dan yang paling penting adalah Shenzen karena dekat dengan Hongkong. Hingga tahun 1986, penanaman modal asing di propinsi tersebut mencapai 1000 perusahaan. Soviet hingga akhir tahun 1989 hanya bisa menarik 400 perusahaan melakukan investasi di ZEE-nya. ${ }^{18}$

Ada beberapa keuntungan yang diperoleh dari FDI, antara lain sebagai berikut:

a. Fungsi produksi. FDI dapat mempengaruhi keluaran dengan meningkatkan persediaan modal. Jika modal domestik dan asing saling melengkapi maka agregat produksi akan lebih besar. Jika modal asing diperlakukan dengan cara yang berbeda dari modal yang domestik melalui pengembangan dari barang-barang intermediasi dan barang-barang modal, FDI dapat menaikkan produktivitas di dalam negara penyelenggara

b. FDI juga mempengaruhi tenaga kerja melalui penciptaan peluang kerja, meski bisa dibatasi pada yang jangka pendek. Bagaimanapun, pengaruh penting dalam jangka panjangnya adalah alih teknologi dan ketrampilan bagi peningkatan sumber daya manusia. Bagi ekonomi mitra yang memiliki memiliki pengalaman terbatas;. FDI memperluas kesempatan transfer pengetahuan dengan pelatihan, akuisisi ketrampilan, difusi teknik manajemen dan organisasi baru. Dengan demikian, efisiensi tenaga kerja meningkat dan berguna lebih besar untuk pertumbuhan output. ${ }^{19}$

Manfaat FDI dalam pertumbuhan output tidak bisa dirasakan dalam sistem lama saat menjalankan program teknologinya karena pola produksi berbiaya tinggi tidak membutuhkan efisiensi daripada pencapaian target sehingga lemah dalam menyeimbangkan orientasi produksi berdasar kebutuhan. Tujuan pencapaian target tidak membutuhkan tenaga kerja yang terspesialisasi. Target juga telah mengurangi daya dorong inovasi sehingga lemah untuk mendorong pertumbuhan yang intensiv. 
Kebijakan baru mendorong menutup kelemahan-kelemahan tersebut. Teknologi menjadi motor untuk meningkatkan efisiensi melalui peningkatan kualitas produksi yang berorientasi pasar. Tenaga kerja harus mempunyai spesialisasi. Efesiensi memerlukan budaya inovasi yang merata di setiap lini produksi. Dengan demikian teknologi sebagai mesin pertumbuhan semakin dibutuhkan dalam era desentralisasi.

FDI telah mebuat negara sosialis merasakan kemajuan teknologi di berbagai bidang. Teknologi telah membawa fleksibiltias dalam melakukan usaha karena mudah dibawa, mengotimalkan kualitas produk yang memuaskan bagi konsumen dan menghilangkan segala kendala tradisional yang mengitari proses desain, produksi, dan penjualan. Namun untuk melangkah lebih jauh, dengan menciptakan sesuatu yang baru dan inovatif belum dirasakan manfaatnya dalam jangka pendek masih memerlukan pertumbangan. Penggunaan dan pengembangan teknologi yang memerlukan biaya tinggi untuk sementara ditangguhakan. Semuanya akan berpengaruh negatif terhadap pertumbuhan. Karena itu, seleksi teknologi yang sesuai dengan tujuan pertumbuhan diperlukan. Dorongan optimalisasi pertumbuhan melalui proses intensifikasi usaha lebih kuat sehingga pemanfaatan teknologi dilakukan dalam kerangka tersebut.

\section{Insentif}

Bagi Hamid, persoalan insentif inilah yang harus segera diselesaikan oleh penganut ekonomi socialis. ${ }^{20} \mathrm{Hal}$ itulah yang menjadi tantangan paling besar karena mengenalkan sistem yang berakar kuat pada pasar dalam sebuah sistem yang berkarakter komando memerlukan pertimbangan dan penerapan yang matang tanpa menimbulkan sikap apatis terhadap aktivitas ekonomi.

Bias pada sistem klasik terjadi karena intervensi birokrat yang besar dalam persoalan ekonomi. Insentif material dikurangi dengan mengedepankan nilai-nilai kebersamaan. Karena itu, performa produksi pertumbuhan seiring loyalitas dan relasi politik memberikan insentif yang besar daripada mengutamakan aspek pertama. Desentralisasi mengembalikan sistem insentif seseuai dengan nilai-nilai umum dalam ekonomi dengan mengurangi ukuranukuran politis.

USSR dan RRC mengeluarkan kebijakan yang sama untuk dalam reformasi di bidang insentif. Keduanya menggunakan model lama yang telah 
dikembangkan oleh Liberman dan diterapkan di USSR pada tahun 1965. Proposal Liberman memberikan sekat kuat dari intervensi politik dengan mengajukan kontrak perjanjian antara negara dan perusahaan yang berisi target dan kuota yang harus dipenuhi oleh perusahaan dalam berproduksi serta kewajiban-kewajiban perusahaan kepada Negara dan masyarakat. Sebagai imbalan mereka memperoleh kebebasan untuk mengelola dan merencanakan produksi. Petani leluasa untuk merencanakan program pertanian sesuai dengan kehendaknya sendiri, para manajer perusahaan bisa merencanakana dan memproduksi sesuai dengan kebutuhan pasar. Output yang melebihi target akan menguntungkan para pnegelola ekonomi, petani bebas menentukan untuk apa sisa target digunakan, perusahaan mendapat bonus prosentase profit atas hasil jerih payahnya.

Pada tahun 1978, Pemerintah RRC melakukan terobosan dengan memberikan otonomi lebih luas kepada buruh tani untuk berusaha secara mandiri dengan memulai proses dekolektivisasi lahan, yaitu pemberian kesempatan kepada individu-individu petani untuk menyewa lahan pertanian dalam jangka panjang untuk diolah secara mandiri. Mereka dihadapkan dengan kontrak perjanjian ( pao kan tau hu). berisi target yang harus dicapai dan kewajiban yang harus dipenuhi terhadap negara. Kewajiban ini diiringi pemberian hak keleluasaan dalam pengambilan keputusan tentang bagaimana pengelolaan lahan dan insentif kepemilikan terhadap sisa target bila hasil melebihi target. Kebijakan ini berhasil meningkatkan hasil panen pertanian hingga $34 \%$ selama 1978-1984. produktivitas total faktor meningkat hingga $28 \% .{ }^{21}$ Keberhasilan eksperimen pada sektor pertanian diperluas pada sektor industri, baik yang dikuasai oleh negara ataupun privat. Perusahan terikat kontrak (Yin k'ui pao kan). Perusahaan diminta untuk mengikat kontrak dengan menyebutkan detil target dan kuota, relasi antar buruh dan profit yang harus diserahkan kepada pemerintah. ${ }^{22}$

Soviet sendiri memulai kembali penggunaan model lama itu dengan memberikan kontrak kepada perusahaan industri yang berisi 5 target; output, pengembangan teknologi, investasi, suplai bahan baku dan keuangan pada tahun 1984. Dekolektivisasi lahan pertanian seperti yang dikembangkan oleh Cina baru dimulai pada tahun 1988. 
Dengan target dan kuota yang ada dalam kontrak, mekanisme insentif dalam pembangunan tidak terlepas dari perencanaan pemerintah. Perencanaan merupakan hal yang mutlak dikuasai oleh pemerintah pusat (partai) untuk mempertahankan prioritas pembangunan yang telah ditetapkannya. Carson mengutip pernyataan sumber resmi pemerintah RRC, ekonomi terencana memainkan peran utama sementara regulasi pasar bersifat sekunder, hanya dengan pengaplikasian perencanaan wajib (mandatory planning) ekonomi, Cina bisa disebut dengan ekonomi terencana. ${ }^{23}$

Untuk Cina, target dan kuota kontrak beracuan pada target pembangunan berbasis pada hasil keputusan tentang sasaran fundamental pembangunan hingga tahun 2000 pada konggres ke 12 Central Committee Party (CCP) pada tahun 1982. Fokus pembangunan meliputi bidang industri, pertanian, energi, transportasi, pendidikan dan pengetahuan. Penyusunan detil target tersebut baru selesai disusun pada tahun 1984 .

Menurut penggagas insentif berdasarkan kontrak; Liberman; kebijakan ini tidak bertentangan dengan sistem perencanaan terpusat. Implementasinya dimaksudkan untuk menstimulasi perusahaan dan pertanian menciptakan profit dalam usahanya. Profit tidak diartikan sebagai tujuan utama seperti yang terjadi dalam sistem kapitalisme, namun hanya menjadi sarana untuk mencapai tujuan pemuasan kebutuhan publik. Profit hanya digunakan sebagai indikator dan insentif efisiensi produksi dalam menghasilkan output yang memuaskan kebutuhan kosumen dan produsen selain untuk kepentingan akumulasi dan investasi. ${ }^{24}$

Oleh karena itu, intervensi pemerintah dalam bidang produksi melalui kontrak hanya untuk memudahkan melakukan perencanaan dan manajerial pembangunan. Perencana melakukan kontrol langsung untuk mengetahui bagaimana implementasi perencanaan dan memperoleh data-data untuk memperkuat basis pertumbuhan ekonomi. Keterlibatan tidak dapat dibahasakan sebagai intervensi langsung terhadap mekanisme pasar karena semua dilakukan dalam rangka melaksanakan fungsi pengaturan ekonomi makro. Rencana itu adalah media jangka panjang yang ditujukan pada pengarahan ekonomi pada satu tingkatan aggregat kebijakan-kebijakan pengendalian ekonomi tidak langsung, pemeliharaan keseimbangan antar sektor dan indikator ekonomi. Kontrak juga dimaknai mempunyai fungsi memandu 
mengenai proyek, produk dan konstruksi penting untuk kepentingan ekonomi nasional .

Dengan melihat pemerintah dalam perpektif makro, perusahaan tidak terkungkung dengan dengan kontrak. Mereka masih bebas untuk menjalankan aktivitas mikro dengan mangalokasikan sumber daya hingga titik profit tertinggi. Pimpinan perusahaan berhak memutuskan investasiinvestasi yang berkategori rendah, perekrutan tenaga kerja dan suplai bahan baku, teknologi yang dipakai dan hal lain yang bermanfaat untuk meningkatkan profit di masa datang. Sama seperti sektor pertanian, perusahaan yang berhasil mencapai target memperoleh insentif bonus berupa prosentase keuntungan. Dengan demikian sistem kontrak menjadi simbol perpaduan antara sistem komando dan pasar.

\section{PENUTUP}

Meski berbeda penekanan pada tiap negara sosialis, Proses reformasi ekonomi sosialis merupakan proses desentralisasi yang memadukan perencanaan pemerintah dan mekanisme pasar untuk meningkatkan pertumbuhan ekonomi. Implementasi jangka panjang masih memerlukan persiapan birokrasi yang matang. Dalam tataran paling rendah, posisi perencana masih bisa menyebabkan penyimpangan implementasi reformasi yang berakibat pada ketidakstabilan ekonomi dan kegagalan untuk mendorong tujuan independensi perusahaan.

Kebijakan penarikan investasi langsung luar negeri memberikan pengaruh dalam modernisasi teknologi dalam negeri. Namun stabilitas politik dan nilai mata uang menjadi problem terbesar terhadap keamananan investasi. Apabila pemerintah melakukan overlap, kebijakannya dipandang sebagai keterlibatan birokrasi dalam pasar dan bisa berakibat buruk terutama saat kondisi politik sedang menurun.

Bagi perusahaan kebutuhan fleksibiltas sangat tinggi untuk menanggapi reaksi pasar, target dan kuota bisa menjadi hambatan ketika kebutuhan tersebut sangat mendesak seperti penjualan produk baru atau perluasan pasar. Persetujuan dari birokrasi bisa menjadi hambatan untuk merespon kebutuhan konsumen dengan cepat yang berarti kehilangan kesempatan profit. 


\section{DAFTAR PUSTAKA}

Carsons, Richard L., Comparative Economic Sistems, USA: M.E. Sharpe Inc., 1990.

Gonçalves, Por Arnaldo, "China's Swing From a Planned Soviet-Type Economy to an Ingenious Sosialist Market Economy: an Account of 50 Years", http://ssrn.com/abstract $=604955$

Hamid , Edi Suandi, Modul Sistem Ekonomi, Ttp. : Universitas Terbuka, 2007

Heilbroner, Robert, "Sosialism", http://www.econlib.org/ Sosialism.html

Jan Hanousek dan Randall K. Filler, Lange and Hayek Revisited: Lessons from Czech Voucher Privatization, CERGE-EI Working Paper No. 166. December 2000,

Madison, Angus, Chinese Economic Performance In The Long Run, USA : Development Centre Studies, 2007.

Nauro F. Campos and Yuko Kinoshita, Foreign Direct Investment as Technology Transferred: Some Panel Evidence from the Transition Economies, William Davidson Working Paper No 438,

"Sosialist_market_economy", http:// en.wikipedia.org /wiki /Sosialist _market_economy html

W.J. Samuels, J.E. Biddle, JB. Davis, Blackwell Companion to History Economic Thought 2003, USA: Blackwell Publishing Ltd. 2003, p. 190-191;

Wikipedia, "Lange Model", http://en.wikipedia.org/w/ index.php?title= Lange Model\&action= edit\&section=1

Zweynert, Joachim, Economic Ideas and Institutional Change: Evidence from Soviet, Economic Discourse 1987-1991, Jerman, Hamburg Institute of International Economics, 2004 